\title{
Quercetin Mitigates Vanadium-Pentoxide-Induced Oxidative Stress and Reproductive-Hormone Disruption in Male Rats
}

\author{
Tamer S Imam ${ }^{1}$, Walaa M. Elhady ${ }^{1}$, Rasha Thabet Metwaly Alam ${ }^{2}$, Haiam A Mohammed ${ }^{3}$
}

${ }^{1}$ Department of Forensic Medicine and Toxicology, Faculty of Veterinary Medicine, Zagazig University, Zagazig 44511, Sharkia, Egypt; ${ }^{2}$ Department of Clinical Pathology, Faculty of Veterinary Medicine, Zagazig University, Zagazig 44511, Sharkia, Egypt; ${ }^{3}$ Department of Physiology, Faculty of Veterinary Medicine, Zagazig University, Zagazig 44511, Sharkia, Egypt.

\begin{abstract}
Vanadium pentoxide (VP) is a well-defined industrial pollutant, known to adversely affect the reproductive functions of male. This work was done to study the protective activities of the quercetin against VP; we have studied reproductive alterations associated with VP by oxidative stress and deleterious changes on testicular function. Treatment with VP, in male rats, resulted in reduction of serum total testosterone and LH, and an elevation in the LDH levels. It led to prominent spermatogenic arrest, decreased the motility percent of sperm and count, and also increased the sperm abnormality. The testicular acid phosphatase was elevated, and GSH and CAT levels were reduced, whereas malondialdehyde levels elevated. Additionally, VP reduced actin testicular cytoskeleton immunostaining in myoid cells. In response to concurrent treatment with quercetin and VP, serum hormones, $\mathrm{LDH}$, and sperm quality were improved. Moreover, it reduced oxidative stress by reduction of malondialdehyde and elevation of GSH and CAT activity. Also, Ih increased actin cytoskeleton immunostaining.
\end{abstract}

Keywords | Vanadium, Oxidative stress, Immunohistochemistry, Quercetin, Rats.

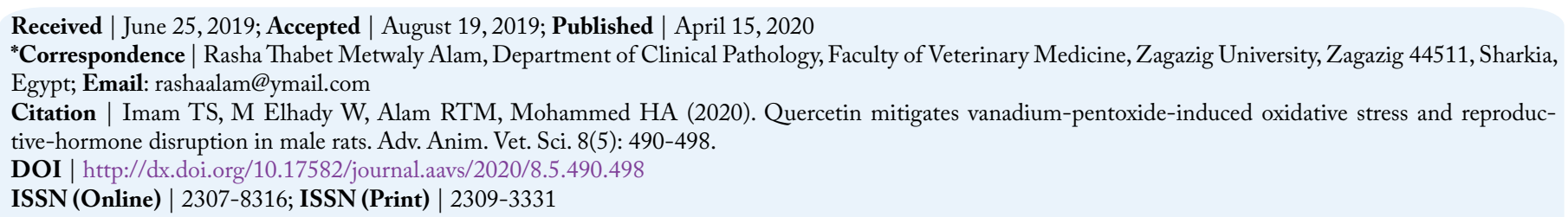

Copyright ( 92020 Alam et al. This is an open access article distributed under the Creative Commons Attribution License, which permits unrestricted use, distribution, and reproduction in any medium, provided the original work is properly cited.

\section{INTRODUCTION}

$\mathrm{V}$ anadium pentoxide $\left(\mathrm{VP} ; \mathrm{V}_{2} \mathrm{O}_{5}\right)$ is coming from an industrial perspective, the most important stable salt of vanadium, it is used as an oxidizing agent, a catalyst, and vanadium alloys production (Budavari et al., 1996; Rivedal et al., 1990; Rojas et al., 1996). Vanadium-containing compounds derived from combustion of fuel products contribute to air pollution. Vanadium compounds also have a number of medicinal uses, including a vaginal contraceptive (D'Cruz et al., 1998), antitumor (Olopade et al., 2009), and anti-diabetic (Hu et al., 2010) agents. Moreover, vanadium compounds have also been shown to produce neurotoxicity in rats (Garcia et al., 2005), enhance the formation of micronucleus (Zhang et al., 1993), and cause DNA damage in human leukocytes (Rojas et al., 1996).
However, VP impairs the function of the cardiovascular system, increases respiratory disorders, and induces alterations in immune responses in mice (Pinon-Zarate et al., 2008). Additionally, VP leads to necrosis of testicular tissues, destruction of seminiferous tubules, and reduction in spermatogonia in guinea pigs (Uche et al., 2008).

Quercetin, a flavonoid which is present in many vegetables and fruits, it has properties that may reduce the risk of infection (Davis et al., 2009), lipid peroxidation and inflammation (Aguirre et al., 2011), as well as helping to protect cells from injury, and to increase antioxidant capacity $(\mathrm{Ca}-$ margo et al., 2011). The antioxidant properties of quercetin make it a hepato-protective agent (Vidhya and Indira, 2009), and it has immunostimulatory and anti-inflammatory properties, including enhancement of immunoglobu- 
lin production and reduction of the certain cytokines release (Alam et al., 2016; Li et al., 2016).

This work was aimed to explore, the protective effects of quercetin against VP toxicity with respect to oxidative stress, sperm parameters, immunohistochemical expression of actin and the histopathology of testicular tissue.

\section{MATERIALS AND METHODS}

\section{Chemicals}

Analytical grade Vanadium oxide $\left(\mathrm{V}_{2} \mathrm{O}_{5}, 223794\right.$, orange powder), was purchased from Sigma (USA, St Saint Louis, MO). Quercetin was prepared daily (dissolved in saline) and purchased from Sigma.

\section{Experimental Animals}

Healthy male adult Wistar albino rats ( 6 weeks old, $n=40$, 150-200 g BW), were obtained from laboratory house of animal (Faculty of Veterinary Medicine, Zagazig University). Animals were kept in cages from metal, at $45-55 \%$ relative humidity and $25^{\circ} \mathrm{C}$, with a light-dark cycle $(12$ h). Basal diet of rodent and water were supplied ad libitum throughout the experiment. Rats underwent a 2-week adaptation period prior to experimentation. Management and housing of the animals, also the experimental design were approved by the ethics committee of research (Faculty of Veterinary Medicine, Zagazig University, Egypt) and performed as stipulated in the Guide for Use and Care of Animals Laboratory Guidelines of the National Health Institutes. Efforts were done to reduce suffering of the animal.

Rats were equally classified into four groups, then given the indicated treatment agents by gavage daily, five times each week, for 65 days. Control group administered distilled water $(0.5 \mathrm{ml})$ per treatment. The quercetin group received quercetin at $50 \mathrm{mg} / \mathrm{kg}$ BW (Ding et al., 2012). The VP group received VP which dissolved in water (distilled) at a dose of $2.5 \mathrm{mg} / \mathrm{kg}$ (one-quarter of the previously determined oral $\mathrm{LD}_{50}$ of $10 \mathrm{mg} / \mathrm{kg}$ [Lewis, 2000]). The quercetin $+\mathrm{VP}$ group received quercetin followed by VP as the group II/III doses.

After 65 days, under light ether anesthesia, rats were euthanized (cervical dislocation). Blood samples $(2 \mathrm{ml})$ were collected from each rat into gelatin-containing vacuum test tubes without anticoagulant for serum separation. The testes were dissected from each rat for further investigation of antioxidant and oxidative-stress markers and histopathology.

\section{Biochemical AnALYSis}

Samples of blood were collected from rats, left for $30 \mathrm{~min}$ (room temperature) to enable clotting, and were centrifuged at $322 \times g$ for $20 \mathrm{~min}$ for serum separation, which was stored $\left(-20^{\circ} \mathrm{C}\right)$ until further use. Total testosterone levels were determined with ELISA kit of rat (China, Cusabio; Wuhan). Serum luteinizing hormone levels was assessed with a rat ELISA kit (USA, MyBioSource; San Diego, CA), and the levels of lactate dehydrogenase were measured according to Buhl and Jackson (1978). Levels of acid phosphatase (ACP) were measured with kits obtained from Quimica Clinica Aplicada Company (Spain, Amposta) according to a previously described method (Moss, 1984). The assay of ACP depends on the p-nitrophenyl-phosphate hydrolysis in acidic medium, with spectrophotometric quantification of liberated $\mathrm{p}$-nitrophenol by absorbance at $420 \mathrm{~nm}$.

\section{Sperm Analysis}

Sperm motility percent: Cauda epididymis was removed from the testis from each rat, placed in $2 \mathrm{ml}$ normal saline at a sterile Petri dish $\left(37^{\circ} \mathrm{C}\right)$, and created a small opening for facilitating the sperm passage to obtain the epididymal suspension (Eleiwa et al., 2018). A drop of the prepared suspension was examined under a light microscope for evaluation of spermatozoon motility; 200 spermatozoa were analzed in five microscopic fields, for assessment the percentage of motility (Slott et al., 1991).

Sperm-cell concentration: The semen suspension was diluted 1:4 in formol saline (containing a little drops of formalin 40\%, for killing the spermatozoa); then the prepared suspension was well mixed and used to count the sperm (Robb et al., 1978).

Sperm abnormalities: The eosin-nigrosin stain (two drops) were mixed with each formalin-treated semen suspension on a microscope slide, and a good film was made, dried in the air, and examined. Each sample, 200 spermatozoa were assessed randomly in different fields for the abnormalities (head and/or tail), and the total abnormality percentage was recorded (Filler, 1993).

Antioxidant enzymes and oxidative-stress markers: One testis was preserved in liquid nitrogen from each rat for enzymatic assessment. Testicular tissue $(1 \mathrm{~g})$ was homogenized with ice-cold phosphate buffer $(10 \mathrm{ml}, 7.4 \mathrm{pH})$ by an electrical homogenizer, and centrifuged for $15 \mathrm{~min}$ at $322 \times g\left(4^{\circ} \mathrm{C}\right)$. The supernatant was collected and preserved $\left(-80^{\circ} \mathrm{C}\right)$ until use. Levels of testicular reduced glutathione (GSH) were estimated according to Beutler et al. (1963), catalase was determined according to Aebi (1984), and the concentration of malondialdehyde was assessed according to Mihara and Uchiyama (1978).

Immunohistochemistry: Tissue sections $(5 \mu \mathrm{m})$ from the testis were placed on slides coated with poly-L-ly- 
sine, then dewaxed $\left(56^{\circ} \mathrm{C}\right.$ for $\left.30 \mathrm{~min}\right)$ and placed $5 \mathrm{~min}$ in xylene. All sections were hydrated in $96 \%$ ethanol and water (distilled). The expression of actin, smooth muscle Ab-1 ( $\alpha$-SMA) was determined by staining with a mouse monoclonal antibody (Catalog \# MS-113-P0, Thermo Fisher Scientific, Fremont, CA, USA) according to Skalli et al. (1986). After binding of the secondary antibody, positive immunostaining was indicated by the formation of a brown precipitate at the site of binding under light microscopy.

\section{Histopathological Examination}

Samples from the testicular tissue were fixed in formalin, then dehydrated in ethanol (70\%), then cleared in xylene, and finally embedded in paraffin. Sections ( $5 \mu \mathrm{m}$ thick) were cut, mounted on slides, then rehydrated, and stained with H\&E (hematoxylin and eosin) and examined microscopically (Suvarna et al., 2013).

\section{Statistical Analysis}

The data were represented by means $\pm \mathrm{SE}$ for each group, and variations among different groups were analyzed by one-way ANOVA analysis of variance followed by Duncan's multiple ranges post hoc test. A significant differences were considered at $P<0.05$.

\section{RESULTS}

\section{Effects Of Treatment With Quercetin And Vp On Serum Biochemical Parameters}

Compared with control group, serum total testosterone levels were not significantly different in rats administered quercetin, but were lower $(P<0.05)$ in rats administrated VP (Table 1$)$. The serum total testosterone levels were significantly $(P<0.05)$ increased in the quercetin $+\mathrm{VP}$ group when compared with VP intoxicated group, although levels in the combined group were still lower than in the controls. Compared with control rats, serum LH was not vary significantly in the quercetin-administered group, but it was lower $(P<0.05)$ in VP-treated rats. LH levels in rats co-treated with quercetin and VP were higher $(P<0.05)$ than VP group. Serum LDH levels were reduced $(P<0.05)$ in quercetin treated rats and significantly increased in the VP intoxicated rats when compared to control. LDH levels were significantly lower in the co-treated group than VP treated group (Table 1).

\section{EfFects of Treatment With Quercetin and VP on Sperm Parameters}

In relation to sperm quality, compared with the control rats, there was a non-significant change in sperm motility in the quercetin-treated group, but motility was lower $(P<0.05)$ in the VP-treated rats. Motility in the combined (quercetin $+V P$ ) group was significantly $(P<0.05)$ increased than the VP group, and showed a non-significant change in levels in the control (Table 2). Compared to control, the sperm count was significantly $(P<0.05)$ increased in quercetin-treated rats and significantly $(P$ $<0.05)$ lower in VP-treated rats. The count was significantly $(P<0.05)$ increased in the quercetin+VP co-treated rats than in VP-treated group. Compared with control, the rate of sperm abnormality was significantly higher in the VP group, whereas the rate was lower $(P<0.05)$ in the co-treated group than VP-treated group (Figure 1).

Table 1: Effect of quercetin and vanadium pentoxide (VP) treatment on serum biochemical parameters in rats.

$\begin{array}{lllll}\text { Parameter } & \begin{array}{l}\text { Group } \\ \text { Control }\end{array} & \text { Quercetin } & \text { VP } & \begin{array}{l}\text { Quercetin } \\ + \text { VP }\end{array} \\ \begin{array}{lllll}\text { Total tes- } \\ \text { tosterone } \\ \text { (ng/dl) }\end{array} & \pm 352.76 & { }^{\mathrm{a}} 357.23 \pm & { }^{\mathrm{c}} 188.47 \pm & { }^{\mathrm{b}} 230.34 \pm \\ \mathrm{LH}(\mathrm{mIU} / & { }^{\mathrm{a}} 1.30 \pm & 0.91 & 0.75 & 1.48 \\ \mathrm{ml}) & 0.032 & 0.034 & 0.004 & 0.005 \\ \mathrm{LDH}(\mathrm{d} / \mathrm{l}) & \mathrm{c} 152.40 & { }^{\mathrm{d}} 129.80 \pm & { }^{\mathrm{a}} 1546.2 \pm & { }^{\mathrm{b}} 874.00 \pm \\ & \pm 3.48 & 0.37 & 2.73 & 13.84\end{array}$

Values shown are means $\pm \mathrm{SE}(n=5)$. Means within the same row labelled with different superscripts are significantly different $(p \leq 0.05)$.

Control treatment was $0.5 \mathrm{ml} / \mathrm{kg}$ distilled water; quercetin was $50 \mathrm{mg} / \mathrm{kg}$ quercetin; $\mathrm{VP}$ was $2.5 \mathrm{mg} / \mathrm{kg} \mathrm{VP}$; and quercetin+VP was $50 \mathrm{mg} / \mathrm{kg}$ quercetin $+2.5 \mathrm{mg} / \mathrm{kg}$ VP.

Table 2: Effects of quercetin and vanadium pentoxide (VP) treatment on sperm motility \%, count and abnormality $\%$ in male albino rats.

\begin{tabular}{|c|c|c|c|c|}
\hline \multirow[t]{2}{*}{ Parameter } & \multicolumn{4}{|l|}{ Group } \\
\hline & Control & Quercetin & VP & $\begin{array}{l}\text { Quercetin } \\
+\mathrm{VP}\end{array}$ \\
\hline $\begin{array}{l}\text { Sperm } \\
\text { motility \% }\end{array}$ & $\begin{array}{l}{ }^{a} 85.00 \pm \\
1.58\end{array}$ & $\begin{array}{l}{ }^{a} 84.00 \pm \\
1.87\end{array}$ & $\begin{array}{l}\text { b } 69.00 \pm \\
1.00\end{array}$ & $\begin{array}{l}{ }^{\mathrm{a}} 84.00 \pm \\
1.00\end{array}$ \\
\hline $\begin{array}{l}\text { Sperm count } \\
(\mathrm{mL} \times \\
\left.125 \times 10^{4}\right)\end{array}$ & $\begin{array}{l}\text { b73.20 } \\
0.96\end{array}$ & $\begin{array}{l}\text { a } 85.00 \pm \\
1.09\end{array}$ & $\begin{array}{l}\mathrm{d} 40.60 \pm \\
0.51\end{array}$ & $\begin{array}{l}\mathrm{c} 68.00 \pm \\
1.22\end{array}$ \\
\hline $\begin{array}{l}\text { Sperm ab- } \\
\text { normalities } \%\end{array}$ & $\begin{array}{l}c 9.60 \pm \\
0.20\end{array}$ & $\begin{array}{l}c 10.01 \pm \\
0.26\end{array}$ & $\begin{array}{l}23.86 \pm \\
0.84\end{array}$ & $\begin{array}{l}\text { b16.96 } 16 . \\
0.41\end{array}$ \\
\hline
\end{tabular}

Values shown are means $\pm \mathrm{SE}(n=5)$. Means within the same row labelled with different superscripts are significantly different $(p \leq 0.05)$.

Control treatment was $0.5 \mathrm{ml} / \mathrm{kg}$ distilled water; quercetin was $50 \mathrm{mg} / \mathrm{kg}$ quercetin; VP was $2.5 \mathrm{mg} / \mathrm{kg} \mathrm{VP}$; and quercetin+VP was $50 \mathrm{mg} / \mathrm{kg}$ quercetin $+2.5 \mathrm{mg} / \mathrm{kg} \mathrm{VP}$.

Effects of Treatment with Quercetin and Vp on Antioxidant/Oxidative Stress Markers in Testicular Tissue

Quercetin administration did not significantly affect testi- 


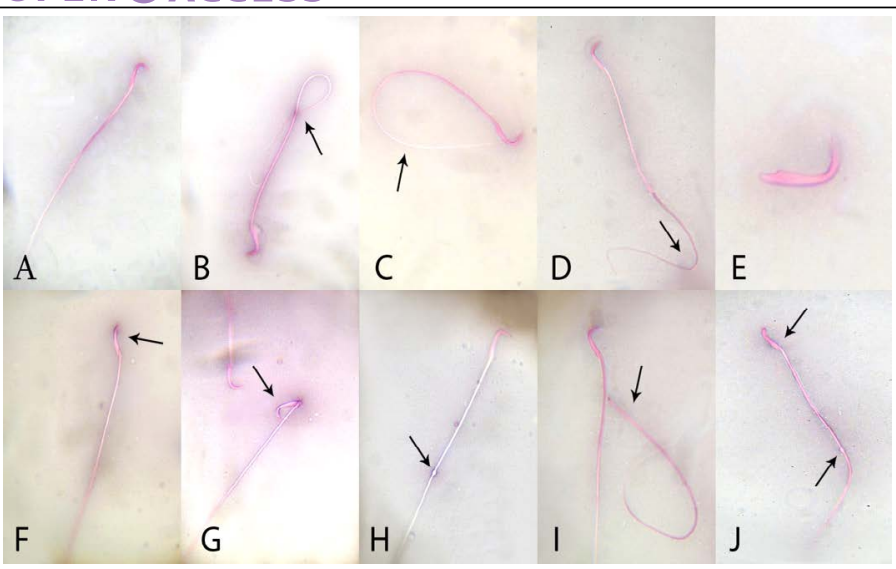

Figure 1: Effects of administration vanadium pentoxide on sperm morphology in rats. A) normal sperm, (B) coiled tail, (C) looped tail, (D) curved tail, (E) detached head, (F) abnormal head shape, $(\mathrm{G})$ broken head, $(\mathrm{H})$ cytoplasmic droplet, (I) detached head, and (J) straight head with cytoplasmic droplet (original magnification 100×; eosin and nigrosine stains).

Table 3: Effect of quercetin and vanadium pentoxide (VP) treatment on antioxidant/oxidative-stress markers of testicular tissue in rats.

\begin{tabular}{|c|c|c|c|c|}
\hline \multirow[t]{2}{*}{ Parameter } & \multicolumn{4}{|l|}{ Group } \\
\hline & Control & Quercetin & VP & $\begin{array}{l}\text { Quercetin } \\
+V P\end{array}$ \\
\hline $\begin{array}{l}\text { Acid phos- } \\
\text { phatase (U/g) }\end{array}$ & $\begin{array}{l}85.98 \pm \\
0.98\end{array}$ & $\begin{array}{l}c 86.01 \pm \\
0.75\end{array}$ & $\begin{array}{l}{ }^{\mathrm{a}} 133.07 \\
\pm 0.59\end{array}$ & $\begin{array}{l}{ }^{\mathrm{b}} 111.56 \pm \\
0.23\end{array}$ \\
\hline $\begin{array}{l}\text { Glutathione } \\
(\mathrm{mmol} / \mathrm{g})\end{array}$ & $\begin{array}{l}29.87 \pm \\
0.021\end{array}$ & $\begin{array}{l}{ }^{\mathrm{a}} 10.10 \pm \\
0.038\end{array}$ & $\begin{array}{l}c 4.04 \pm \\
0.08\end{array}$ & $\begin{array}{l}\mathrm{b} 6.96 \pm \\
0.27\end{array}$ \\
\hline $\begin{array}{l}\text { Catalase } \\
(\mathrm{U} / \mathrm{g})\end{array}$ & $\begin{array}{l}\mathrm{b} 23.62 \pm \\
0.53\end{array}$ & $\begin{array}{l}27.64 \pm \\
0.74\end{array}$ & $\begin{array}{l}\mathrm{d} 16.87 \pm \\
0.28\end{array}$ & $\begin{array}{l}\mathrm{c} 21.72 \pm \\
0.34\end{array}$ \\
\hline $\begin{array}{l}\text { Malondialde- } \\
\text { hyde (nmo- } \\
1 / g)\end{array}$ & $\begin{array}{l}3.8 \pm \\
0.09\end{array}$ & $\begin{array}{l}\mathrm{d} 1.5 \pm \\
0.13\end{array}$ & $\begin{array}{l}\text { a } 21.45 \pm \\
0.33\end{array}$ & $\begin{array}{l}\mathrm{b} 6.06 \pm \\
0.09\end{array}$ \\
\hline
\end{tabular}

Values shown are means $\pm \mathrm{SE}(n=5)$. Means within the same row labelled with different superscripts are significantly different $(p \leq 0.05)$.

Control treatment was $0.5 \mathrm{ml} / \mathrm{kg}$ distilled water; quercetin was $50 \mathrm{mg} / \mathrm{kg}$ quercetin; VP was $2.5 \mathrm{mg} / \mathrm{kg} \mathrm{VP}$; and quercetin+VP was $50 \mathrm{mg} / \mathrm{kg}$ quercetin $+2.5 \mathrm{mg} / \mathrm{kg}$ VP $(2.5 \mathrm{mg} / \mathrm{kg})$.

cular ACP, whereas VP toxicity provoked a significant $(P$ $<0.05$ ) elevation in ACP compared with control group, and the ACP level in the quercetin+VP group was significantly lower $(P<0.05)$ than VP group (but still higher than control group). The reduced glutathione concentration was lower $(P<0.05)$ in the VP-intoxicated group when compared with control, and significantly $(P<0.05)$ increased in quercetin $+\mathrm{VP}$ co-treated rats than VP-treated rats (but still lower than in the control group). Testicular catalase activity was significantly $(P<0.05)$ increased in quercetin-treated group and decreased in VP-treated group than in controls, and also higher in quercetin $+\mathrm{VP}$ co-treated rats than in VP-treated rats (but still lower than in controls). Lipid peroxidation (malondialdehyde) in testicular tissue was lower in quercetin-treated rats and increased $(P$ $<0.05)$ in VP-treated rats than in controls, and significantly $(P<0.05)$ lower in the co-treated group compared to VP-treated group (but still higher than in controls). Table (3).

\section{Effects of Quercetin and Vp Treatment on Actin Immunostaining in Testicular Tissue}

Immunohistochemical examination of testicular tissue revealed alterations in the myoid cells through $\alpha$-SMA immunostaining. The control and quercetin-treated groups showed strong $\alpha$-SMA immunostaining which represented by brown expression, whereas VP-treated rats showed weak $\alpha$-SMA immunostaining, and the quercetin+VP co-treated rats showed moderate $\alpha$-SMA immunostaining (Figure 2).
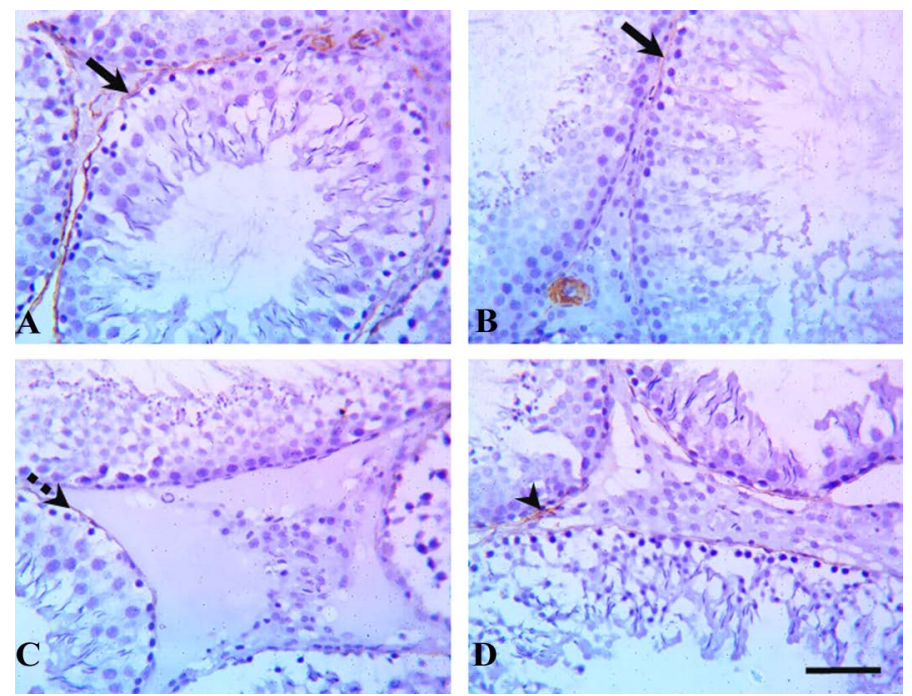

Figure 2: Testicular $\alpha$-smooth-muscle actin ( $\alpha$-SMA) immunostaining in rats treated with quercetin and vanadium pentoxide (VP). Representative photomicrographs show changes in myoid cells (brown pigment) via $\alpha$-SMA immunostaining of testicular sections in (A) control, (B) quercetin-treated, (C) VP-treated, and (D) quercetin and VP co-treated groups. The control and quercetin-treated groups showed positive, strong $\alpha$-SMA immunostaining (solid arrows), whereas VP-treated rats showed weak $\alpha$-SMA immunostaining (dashed arrow), and the quercetin and VP co-treated rats showed moderate $\alpha$-SMA immunostaining (arrowhead). Scale bar: $50 \mu \mathrm{m}$.

\section{Effects of Treatment with Quercetin and Vp} on Testicular Histopathology

Histopathological evaluation of testicular tissues revealed normal histological architectures of closely packed seminiferous tubules lined with seminiferous epithelial cells and interstitial tissue containing Leydig cells in the control and quercetin-treated group (Figure 3). In the VP-treat- 
ed group, severe germinal epithelial atrophy was observed, and interstitial tissue was replaced with homogenous eosinophilic material and vacuoles. In the quercetin+VP co-treatment group, less histopathological disruption occurred than in the VP-treated group, and a sufficient number of spermatocytes and mild vacuolation of some spermatogonial cells was observed.
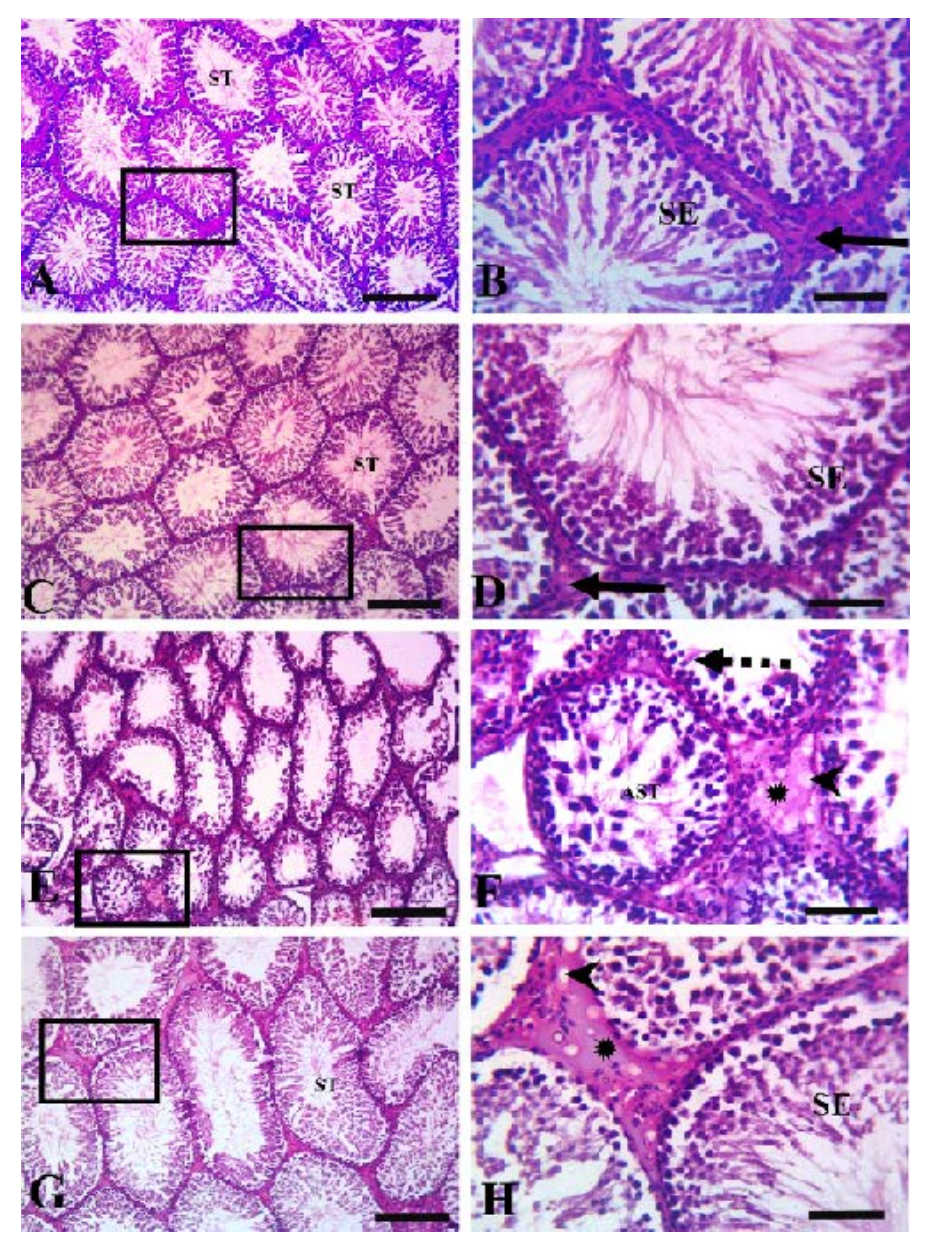

Figure 3: Testicular histopathology in rats treated with quercetin and vanadium pentoxide (VP). Photomicrographs of testicular sections. Control group (A $\& B)$, quercetin group $(\mathrm{C} \& D), V P$ treated-group $(\mathrm{E} \& \mathrm{~F})$, quercetin $+\mathrm{VP}$ treated-group $(\mathrm{G} \& \mathrm{H}) \cdot \mathrm{B}, \mathrm{D}, \mathrm{F}, \mathrm{H}$ represents higher magnifications of the boxed area in $\mathrm{A}, \mathrm{C}, \mathrm{E}$, and $\mathrm{G}$, respectively. The control and quercetin-treated rats (A, B, C, and D) showed normal histological structures of closely packed seminiferous tubules (ST) lined with seminiferous epithelial cells (SE), and interstitial tissue containing Leydig cells (solid arrows). The VP-treated group (E and F) showed severe germinal epithelial atrophy (dashed arrows), with interstitial tissue replaced with homogenous eosinophilic materials (asterisk) and vacuoles (arrowheads). VP-induced abnormalities were less evident in the VP and quercetin co-treated group ( $\mathrm{G}$ and $\mathrm{H})$. Scale bars A,C, E; $200 \mu \mathrm{m}, \mathrm{B}, \mathrm{D}, \mathrm{F} 50 \mu \mathrm{m}$.

\section{DISCUSSION}

In the present work, rats intoxicated with VP had significant reduction in the serum total testosterone levels than control rats. This may be attributed to VP accumulation in testicular tissues, leading to disruption of cell function, a decrease in the synthesis of testosterone, or inhibition of androgenic enzyme activity in the testes. VP has previously been shown to reduce the growth of accessory sex organs and to decrease androgenesis in rats (Dehghani et al., 2002), that may be related to a reduction in the levels of serum LH. Results from previous studies have also recorded the toxic effects of vanadium in reducing the serum testosterone levels (Chandra et al., 2010; Vijaya Bharathi et al., 2015). These results have now demonstrated that co-treatment of quercetin can, to some extent, counteract the effects of VP treatment on testosterone levels; it is able to increase the levels of serum testosterone in rats (Ma et al., 2004).

$\mathrm{LH}$, which is required for normal spermatogenesis in $\mathrm{pu}^{-}$ berty (Russell et al., 1987), also, is the main regulator of the activities of androgenic enzyme in the testis (Shaw et al., 1979), and is responsible for maintaining normal testosterone levels (Ellis et al., 1982). We found that oral VP administration significantly reduced serum $\mathrm{LH}$ levels relative to those in controls, which may be attributed to stimulation of adrenocortical hormones that consequently suppresses LH secretion from the pituitary gland (D'Agostino et al., 1990). Although quercetin alone did not affect LH levels, simultaneous administration of quercetin and VP elevated serum $\mathrm{LH}$ relative to $\mathrm{VP}$ alone, possibly via direct stimulation of other sex organs to increase the secretion of $\mathrm{LH}$, or by reduction of the accumulation of VP in tissues, thereby counteracting the effect of VP on the pituitary gland, and maintaining the level of $\mathrm{LH}$.

$\mathrm{LDH}$ is an intracellular enzyme that is another index for VP toxicity. Our results have shown that serum activity of $\mathrm{LDH}$ is elevated in rats intoxicated with VP, which may be attributed to the interaction of accumulated vanadium with LDH and a coenzyme system (Kanthasamy et al., 1988; Shrivastava et al., 2007). Additionally, the activity of intracellular LDH significantly increased by VP treatment (Song et al., 1998), and this activity has been shown to be associated with damage in Sertoli and germ cells (Pant and Srivastava, 2003), and LDH rapid release to the circulation after membrane damage. Our results showed that quercetin alone reduced LDH activity, and that administration of quercetin with VP reduced LDH activity compared with VP alone, suggesting the prevention of testicular injury, possibly by reduction of $\mathrm{LDH}$ release from cells (Zou et al., 2010; Kumar et al., 2016) through minimizing the oxidative stress and maintaining the cellular integrity. 
VP toxicity leads to clinical problems such as impairment of spermatogenic activity and reduction of male fertility. Our results indicated that VP intoxication affects spermatogenesis, resulting in a decrease in the sperm motility percentage and count, with an elevation the sperm abnormality percentage, which may be attributed to accumulation of VP and/or its metabolites in the testes. This accumulation of VP has been shown to cause reductions in expression of gamma-tubulin in testicular tissue, which may affect the spermatogenic process and cell division in the testes (Mussali-Galante et al., 2005). Chronic vanadium toxicity might also interfere with the production of testosterone, thereby decreasing sperm count and motility in association with excessive reactive oxygen species and lipid peroxidation production in the testes (Jain et al., 2007). Moreover, vanadium toxicity may increase levels of sperm-cell abnormalities (Cooper, 2007; Uche et al., 2008; Vijaya Bharathi et al., 2015). By contrast, quercetin has an androgenic effect, and it can ameliorate the toxic effect of VP in the co-treated rats by improving sperm quality (concentration, viability, and motility), which may be attributed to stimulation of epidydimal and testicular function (Taepongsorat et al., 2008) and stimulation of the secretion of testosterone from the hypothalamic-pituitary-gonadal axis (Ma et al., 2004).

ACP, a testicular enzyme that is located in the lysosomes of Leydig cells, is a sensitive marker of VP toxic effects on spermatogenesis in the male reproductive system. We observed elevated testicular ACP activity in VP-treated rats, indicating degeneration of the testes, which may be a consequence of a low level of testosterone. Vanadium toxicity has previously been shown to increase the activity of ACP measured in guinea pig testes (Uche et al., 2008). Elevation of ACP by VP was mitigated by quercetin, which may be due to protection of testicular tissue from degeneration by toxic agents.

We found that VP toxicity significantly reduced testicular glutathione and catalase levels, and elevated malondialdehyde levels, possibly through accumulation of VP and/or its metabolites in the testes, leading to damage of cellular enzymes (Donaldson et al., 1985) and an increase in the release of inflammatory cytokines and chemokine from cells (Cooper, 2007), that exhaust antioxidant enzymes to overcome the oxidative stress, resulting in injury and degeneration of testicular tissue. Our results suggest that elevation of malondialdehyde levels may be related to the failure of cellular antioxidant defenses, such as glutathione and catalase. Similar findings have been made previously by Chandra et al. (2007) and Vijaya Bharathi et al. (2015).We found that quercetin provided some protection from these effects of VP, with co-treatment leading to increased cellular glutathione and catalase levels and decreased malondialdehyde in testicular tissues, compared with VP alone.
Quercetin has previously been identified as a highly effective antioxidant agent (Azab et al., 2013), and it may act as a free-radical scavenging and ion-chelating agent (Joshi et al., 2011), thereby elevating cellular antioxidant-enzyme levels. Furthermore, quercetin is able to reduce lipid peroxidation of the cell membrane and inflammatory reactions in injured tissues (Aguirre et al., 2011; Alam et al., 2016; Li et al., 2016). Antioxidant nature of quercetin also explains its ability to mitigate testicular damage induced by VP, which is attributed to free radical reactions which induce oxidative stress that cause DNA damage and breakage (Sakurai et al., 1995; Shi et al., 1996; Aherne and O'Brien, 2000).

Actin is one of the main cytoskeletal proteins which regulate the process of spermatogenesis in the testes. This protein is involved in cell division, organization, and morphology, as well as the integrity of hematotesticular barrier. We found that VP, which produces changes in the normal function of the testes that lead to infertility, decreased myoid-cell actin immunostaining in the testicular tissue. Similar results have previously been obtained in mice (Rodríguez-Lara et al., 2016). Vanadium compounds induce alterations in actin, by rotein tyrosine phosphatases inhibition (Bennett et al., 1993; Ramos et al., 2011), and can also affect actin polymerization. Our results agree with those of Rodr1'guez-Lara et al. (2016). Damage to the actin cytoskeleton could explain the toxic effects of VP associated with impairment of fertility. Concurrent treatment with quercetin might have reduced the damaging effect of VP on actin by virtue of the antioxidant effects of quercetin, and might also have reduced the accumulation of VP in testicular tissue, protecting the cell membrane from oxidative stress.

All of our results indicating the testicular toxicity of VP were corroborated by the histopathology of the testes, which showed cystic dilatation of the seminiferous tubules, severe interstitial edema, spermatogenesis arrest with few spermatocytes and vacuolation of the spermatogonial cells and Leydig cells. Similarly, the protective effect of quercetin in relation to VP toxicity was evident in the reduction of histopathological disruption in the presence of quercetin.

Taken together, our study indicates that VP induces disturbances in male androgenic activities and testicular functions in rats, but that concurrent treatment with quercetin can reduce the induction of oxidative damage by VP and maintain normal steroidogenesis. Our results suggest the feasibility of using this natural antioxidant to mitigate the VP deleterious effects in male reproductive organs.

\section{ACKNOWLEDGMENTS}

The authors wish to thank Dr. Nesma Ebrahim, lecturer of 
OPEN OACCESS

Histology, Zagazig University for technical assistance in processing the tissue for immunohistochemistry and histopathological examination.

\section{CONFLICTS OF INTEREST}

The authors declare no conflicts of interest.

\section{AUTHOR CONTRIBUTIONS}

Imam T. S. and W. M. Elhady performed the majority of the experiments and contributed to the data analysis and R.T.M. Alam wrote the manuscript, designed, supervised the study and checked the final manuscript.

\section{REFERENCES}

- Aebi H (1984). Catalase in vitro. Meth. Enzymol. 105(13):121-126. https://doi.org/10.1016/S00766879(84)05016-3

-Aherne SA, O'Brien NM (2000). Mechanism of protection by the flavonoids, quercetin and rutin, against tertutylhydroperoxide- and menadione-induced DNA single strand breaks in Caco-2 cells. Free Radic. Biol. Med. 29(6):507-14. https://doi.org/10.1016/S08915849(00)00360-9

-Alam RTM, Abu Zeid EH, Imam TS (2017). Protective role of quercetin against hematotoxic and immunotoxic effects of furan in rats. Environ. Sci. Pollut. Res. 24(4):3780-3789. https://doi.org/10.1007/s11356-016-8108-9

- Aguirre L, Arias N, Macarulla MT, Gracia A, Portillo MP (2011). Beneficial effects of quercetin on obesity and diabetes. Open Nutraceut. J. 4(2015):189-198. https://doi. org/10.2174/1876396001104010189

-Azab SS,Abdel-Daim M,Eldahshan OA (2013).Phytochemical, cytotoxic, hepatoprotective and antioxidant properties of Delonix regia leaves extract. Med. Chem. Res. 22(9):42694277. https://doi.org/10.1007/s00044-012-0420-4

- Bennett PA, Dixon RJ, Kellie S (1993). The phosphotyrosine phosphatase inhibitor vanadyl hydroperoxide induces morphological alterations, cytoskeletal rearrangements and increased adhesiveness in rat neutrophil leucocytes. J. Cell Sci. 106(3):891-901.

- Beutler E, Duron O, Kelly BM (1963). Improved method for the determination of blood glutathione. J. Lab. Clin. Med. 61:882-888.

- Budavari S, O’Neil M J, Heckelman PE, Kinneary JF (1996). The Merck index-an encyclopedia of chemicals, drugs and biological. 12 $2^{\text {th }}$ Ed White house station N J Merck \& CO. Inc. 1691-1692.

-Buhl SN,Jackson KY (1978). Optimal conditions and comparison of lactate dehydrogenase catalysis of the lactateto-pyruvate and pyruvate-to-lactate reactions in human serum at 25, 30, and 37 degrees C. Clin. Chem. 24(5):828-831.

- Camargo C, da Silva M, da Silva R, Justo G, GomesMarcondes M, Aoyama H (2011). Inhibition of tumor growth by quercetin with increase of survival and prevention of cachexia in Walker 256 tumor-bearing rats. Biochem. Biophys. Res. Commun. 406 (4):638-642. https://doi. org/10.1016/j.bbrc.2011.02.111
Advances in Animal and Veterinary Sciences

- Chandra AK, Ghosh R, Chatterjee A, Sarkar M (2007). Effects of vanadate on male rat reproductive tract histology, oxidative stress markers and androgenic enzyme activities. J. Inorg. Biochem. 101 (6):944-956. https://doi.org/10.1016/j. jinorgbio.2007.03.003

- Chandra A K, Ghosh R, Chatterjee A, Sarkar M (2010). Protection against vanadium-induced testicular toxicity by testosterone propionate in rats. Toxicology Mechanism and Methods 20:306-315. 46.

- Cooper R. G. (2007). Vanadium pentoxide inhalation. Indian J. Occup. Environ. Med. 11 (3): 97-102. https://doi.org/10.3 109/15376516.2010.485623

-D’Agostino JB, Valadka RJ, Schwartz NB (1990). Differential effect of in vitro glucocorticoids on LH and FSH secretion: dependence of sex of pituitary donor. Endocrinol. 127(2):891-9. https://doi.org/10.1210/endo-127-2-891

-Davis JM, Murphy EA, Carmichael MD (2009). Effects of the dietary flavonoid quercetin upon performance and health. Curr. Sports Med. Rep. 8(4):206-213. https://doi. org/10.1249/JSR.0b013e3181ae8959

- D' cruz OD, Ghosh P, Uckum FM (1998). Spermicidal activity of metallocene complexes containing vanadium (IV) in humans. Biol. Reprod. 58(6):1515-1526 https://doi. org/10.1095/biolreprod58.6.1515

-Ding W, Petibone D, Latendresse J, Pearce M, Muskhelishvili L, White G, Wei Chang C, Mittelstaedt R, Shaddock J, McDaniel L (2012). In vivo genotoxicity of furan in F344 rats at cancer bioassay doses. Toxicol. Appl. Pharmacol. 261(2):164-171. https://doi.org/10.1016/j. taap.2012.03.021

-Dehghani GA, Mansoorzadeh S, Omrani GH (2002). Effects of vanadyl sulphate on spermatogenesis in male rats. Iran. J. Med. Sci. 27(2):95-96.

-Donaldson J, Hemming R, LaBella F (1985). Vanadium exposure enhances lipid peroxidation in the kidney of rats and mice. Can. J. Physiol. Pharmacol. 63(3):196. https:// doi.org/10.1139/y85-037

-Eleiwa NZH, Galal AAA, Abd El-Aziz RM, Hussin EM (2018). Antioxidant activity of Spirulina platensis alleviates doxorubicin-induced oxidative stress and reprotoxicity in male rats. Orient. Pharm. Experimen. Med. 18(2):87-95. https://doi.org/10.1007/s13596-018-0314-1

-Ellis GB, Desjardins C (1982). Male rats secrete luteinizing hormone and testosterone episodically. Endocrinology. 110(5):1637-1648. https://doi.org/10.1210/endo-110-51618

-Filler R (1993). Methods for evaluation of rat epididymal sperm morphology. In: Methods in Toxicology, vol. 3 (Part A). Male Reproductive Toxicology. Chapin RE, Heindel JJ (eds). Academic Press Limited, London, UK 334-343. https://doi. org/10.1016/B978-0-12-461207-5.50025-0

- Garcia GB, Bian Cardi ME, Quirojo AD (2005). Vanadium $(\mathrm{V})$-induced neurotoxicity in the rat central nervous system: A histoimmunohistochemical study. Drug Chem. Toxicol. 28 (3):329-344 https://doi.org/10.1081/DCT-200064496

-Hu R, He C, Liu J, Wu Y, Li J, Feng Z, Huang J, Xi XG, Wu $Z$ (2010). Effects of insulin-mimeticvanadyl-poly (gammaglutamic acid) complex on diabetic rat model. J Pharm. Sci. 99 (7):3041-7. https://doi.org/10.1002/jps.22071

-Jain G C, Pareek H, Sharma S, Bharadwaj M, Khajja BS (2007). Reproductive toxicity of vanadyl sulphate in male rats. J. Health Sci. 53(1):137-141. https://doi.org/10.1248/ jhs.53.137 
- Joshi JU, Gadge SA, D’Mello P, Sinha R, Srivastava S, Govil G (2011). Anti-inflammatory, antioxidant and anticancer activity of quercetin and its analogues. Inter.J. Res. Pharmac. Biomed. Sci. 2 (4):1756-1766.

-Kanthasamy A, Seker N, Govindasamy S (1988). Vanadate substitute's insulin role in chronic experimental diabetes. Indian J. Exp. Biol. 26(10):778-780.

- Kumar NAD, Bevara GB, Kaja LK, Badana AK, Malla RR (2016). Protective effect of 3-O-methyl quercetin and kaempferol from Semecarpus anacardium against $\mathrm{H} 2 \mathrm{O} 2$ induced cytotoxicity in lung and liver cells. BMC Complement. Alternat. Med. 16:376-389. https://doi. org/10.1186/s12906-016-1354-Z

- Li Y, Yao J, Han C, Yang J, Chaudhry M T, Wang S, Liu $\mathrm{H}$, Yin Y (2016). Quercetin, inflammation and immunity. Nutrients. 8 (3): 167. https://doi.org/10.1128/IAI.01088-15

- Lewis R J (2000). Sr Sax's Dangerous Properties of Industrial Materials, $10^{\text {th }}$ Ed., New York, John Wiley and Sons, Inc. 3657-3660.

- Ma Z, Hung Nguyen T, Hoa Huynh T, Tien Do P, Huynh $H$ (2004). Reduction of rat prostate weight by combined quercetin-finasteride treatment is associated with cell cycle deregulation. J. Endocrinol. 181(3): 493-507. https://doi. org/10.1677/joe.0.1810493

- Mihara M, Uchiyama M (1978). Determination of malonaldehyde precursor in tissues by thiobarbituric acid test. Anal. Biochem. 86(1):271-278. https://doi. org/10.1016/0003-2697(78)90342-1

- Moss DW (1984). In: Bergmeyer HU, editor. Method of enzymatic analysis, 3rd edition. Verlag-Chemie. 4: 92-106.

-Mussali-Galante P, Rodríguez-Lara V, Hernández-Tellez B, Avila-Costa M R, Colín-Barenque L, Bizarro-Nevarez P, Martínez-Levy G, Rojas-Lemus M, Piñón-Zarate G, Saldivar-Osorio L, Diaz-Beck P, Herrera-Enríquez M A, Tovar-Sánchez E, Fortoul T I (2005). Inhaled vanadium pentoxide decrease gamma-tubulin of mouse testes at different exposure times. Toxicol. Ind. Health 21(9):215-22 https://doi.org/10.1191/0748233705th232oa.

- Olopade JO, Madhankumar AB, Das A, Todorich B, Liu X, Slagle-Webb B, Liang JJ, Connor J R (2009). Vanadium a possible chemotherapeutic agent against astrocytoma. Proceedings of the 100th annual meeting of the American Association of Cancer Research, Denver Colorado. 50:1344

- Pant N, Srivastava S P (2003). Testicular and spermatotoxic effects of quinalphos in rats. J. Appl. Toxicol. 23(4):271274. https://doi.org/10.1002/jat.919

-Pinon-Zarate G, Rodriguez-Lara V , Rojas-Lemus M, Martinez-Pedraza M, Gonzalez-Villalva A, MussaliGalante P, Fortoul T I, Barquet A, Masso F, Montano L F (2008). Vanadium pentoxide inhalation provokes germinal center hyperplasia and suppressed humoral immune responses. J. Immunotoxicol. 5(2):115-22 https://doi. org/10.1080/15476910802085749

- Ramos S, Almeida R M, Moura J J (2011). Implications of oxidovanadium (IV) binding to actin. Journal of Inorganic Biochemistry 105(6): 777-783. https://doi.org/10.1016/j. jinorgbio.2011.02.010

- Rivedal E, Roseng L, Sanner T (1990). Vanadium compounds promote the induction of morphological transformation of hamster embryo cells with no effect gap junctional cell communicational. Cell boil. Toxicol. 6 (3): 303-314. https:// doi.org/10.1007/BF02443805

-Robb GW, Amann RP, Killian GJ (1978). Daily sperm production and epididymal reserves of pubertal and adult rats. J. Reprod. Fertil. 54(1):103-107. https://doi. org/10.1530/jrf.0.0540103

-Rodr1'guez-Lara V, Morales-Rivero A, Rivera-Cambas AM, Fortoul TI (2016). Vanadium inhalation induces actin changes in mice testicular cells. Toxicol.Indust. Health.32(2): 367-374. https://doi.org/10.1177/0748233713501364

-Rojas E, Valverde M, Herrera L, Altamirano- Lozano M, Ostrsky-Wegman P (1996). Genotoxicity of vanadium pentoxide evaluated by the single gel electrphoresis assay in human lymphocytes. Mutat. Res. 359(2):77-84 https:// doi.org/10.1016/S0165-1161(96)90254-X

- Russell LD, Alger LF, Naquin LG (1987). Hormonal control of pubertal spermatogenesis. Endocrinology. 120(4):16151632. https://doi.org/10.1210/endo-120-4-1615

- Sakurai H,Tamura H, Okatani K (1995). Mechanisms for a new antitumor vanadium complex hydroxyl-radical dependent DNA cleavage by 1-10-phenenthroline vanadyl complex in the presence of hydrogen peroxide. Biochem. Biophys. Res. Commun. 206(1):133-137. https://doi.org/10.1006/ bbrc.1995.1019

- Shi X, Wang P, Jiang H, Mao Y, Ahmed N, Dalal N (1996). Vanadium (IV) causes 29- deoxiguanosine hidroxilation and deoxyribonucleic acid damage via free radical reactions. Ann. Clin. Lab. Sci. 26(1):39-49.

-Shaw MJ, Georgapouls LE, Payne AH (1979). Synergistic

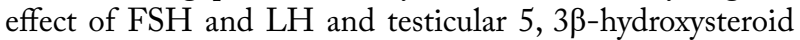
dehydrogenase isomerase. Application of a new method for the separation of testicular compartments. Endocrinology. 104(4):912-918. https://doi.org/10.1210/endo-104-4-912

-Shrivastava S, Jadon A, Shukla S, Mathur R (2007). Chelation therapy and vanadium: Effect on reproductive organs in rats. Indian J. Exp. Biol. 45(6): 515-523.

-Slott V, Suarez J, Perreault S (1991). Rat sperm motility analysis: methodologic considerations. Reprod. Toxicol. 5(5):449458. https://doi.org/10.1016/0890-6238(91)90009-5

- Skalli O, Patricia Ropraz P, Trzeciak A, Benzonana G, Dieter Gillessen D, Gabbiani G A (1986). Monoclonal antibody against a-smooth muscle actin: A New probe for smooth muscle differentiation. J. Cell Biol. 103(6):2787-2796. https://doi.org/10.1083/jcb.103.6.2787

- Song Y, Chen Q, Guan Y (1998). An in vitro study on toxic effect of vanadium-titanium-magnetite dust on alveolar macrophage in rabbits. Zhonghua Yu Fang Yi Xue Za Zhi. 32(6):343-5.

-Suvarna SK, Layton C, Bancroft JD (2013). Bancroft's Theory and Practice of Histological Techniques, 7th edn. Churchill Livingstone, Elsevier, London, England.

-Taepongsorat L, Tangpraprutgul P, Kitana N, Malaivijitnond $S$ (2008). Stimulating effects of quercetin on sperm quality and reproductive organs in adult male rats. Asian J. Androl. 10 (2): 249-258. https://doi.org/10.1111/j.17457262.2008.00306.x

-Uche FI, Obianime AW, Gogo-Abite M (2008). Effects of vanadium pentoxide on the histological and sperm parameters of male Guinea Pigs. J. Appl. Sci. Environ. Manage. 12 (3): 107-115. https://doi.org/10.4314/jasem. v12i3.55512

-Vidhya A, Indira M (2009). Protective effect of quercetin in the regression of ethanol-induced hepatotoxicity. Indian J. Pharm. Sci. 71(5):527-532. https://doi.org/10.4103/0250474X.58186

- Vijaya Bharathi B, Jaya Prakash G, Krishna K M, Ravi 
Krishna C H, Sivanarayana T, Madan K, Rama Raju G A, Annapurna A (2015). Protective effect of alpha glucosyl hesperidin (G-hesperidin) on chronic vanadium induced testicular toxicity and sperm nuclear DNA damage in male Sprague Dawley rats. Andrologia. 47(5):568-578. https:// doi.org/10.1111/and.12304

-Zhang T, Gou X, Yang and Z (1993). Study on teratogenicity
Advances in Animal and Veterinary Sciences and sensitivity period of vanadium pentoxide in $\mathrm{W}$ istar rats. Hua His 1 Ko Ta Hsueh Hsueh. Pao. 24(2):202-205

-Zou YP,Lu YH, Wei DZ (2010).Protective effects of a flavonoidrich extract of Hypericum perforatum L. against hydrogen peroxide-induced apoptosis in PC12 cells. Phytother Res. 24(1): S6-S10. https://doi.org/10.1002/ptr.2852 